\title{
DIGITALCOMMONS
}

@WAYNESTATE —

Wayne State University

$12-1-2013$

\section{From Generation to Generation: The Genetics of Jewish Populations}

Noah A. Rosenberg

Stanford University,noahr@stanford.edu

Steven P. Weitzman

Stanford University

\section{Recommended Citation}

Rosenberg, Noah A. and Weitzman, Steven P., "From Generation to Generation: The Genetics of Jewish Populations" (2013). Human Biology Open Access Pre-Prints. Paper 39.

http://digitalcommons.wayne.edu/humbiol_preprints/39

This Open Access Preprint is brought to you for free and open access by the WSU Press at DigitalCommons@WayneState. It has been accepted for inclusion in Human Biology Open Access Pre-Prints by an authorized administrator of DigitalCommons@WayneState. 


\title{
From Generation to Generation: The Genetics of Jewish Populations
}

\author{
Noah A Rosenberg ${ }^{1}$, Steven P Weitzman ${ }^{2}$ \\ ${ }^{1}$ Department of Biology, Stanford University, Stanford, CA 94305 USA \\ ${ }^{2}$ Taube Center for Jewish Studies, Stanford University, Stanford, CA 94305 USA
}

November 6, 2013 (editorial to appear in 2014)

This year marks the 35th anniversary of two noteworthy papers-one in this journal and the other in the American Journal of Human Genetics-posing the same famous question: are the different Jewish populations from around Europe, the Middle East, and North Africa more genetically similar to each other, or are they more similar to the local non-Jewish populations in the regions where they were historically located? Both studies gathered blood-group and protein variation data from a variety of Jewish and non-Jewish populations, compiling significant "classical marker" data sets commensurate with the standard for human populationgenetic studies at the time.

Writing in the American Journal of Human Genetics, Sam Karlin, Ron Kenett \& Batsheva Bonné-Tamir reported "We found the Ashkenazi, Sephardi, and Iraqi Jewish populations to be consistently close in genetic constitution and distant from all the other populations," concluding that in fact, the Jewish populations were generally more genetically similar to each other (Karlin et al. 1979). In Human Biology, Dorit Carmelli \& Luca Cavalli-Sforza wrote "A wide scatter of the Jews was observed among clusters of non-Jews," finding that on the contrary, the Jewish groups were largely more similar to the local non-Jewish populations (Carmelli \& Cavalli-Sforza 1979).

While these studies used some of the best statistics and data available at the time, they highlight the dramatic changes that have taken place in human population genetics research over the last 35 years. The field has proceeded through a succession of new types of genetic markers, the size of classical data sets has been spectacularly superseded, and the effort to understand new and larger collections of markers has provided many novel methods to the statistical toolbox of population genetics. Further, it has become clear that levels of similarity in human populations are sufficient that the resolution of population relationships among closely related groups often requires both an amount of data and a computational capacity that would have been unimaginable to researchers working in 1979.

What has not changed, however, is that interest in questions of the genetics of Jewish populations has persisted-and in fact, it has intensified. From the viewpoint of population genetics, the history of the various Jewish populations provides a scenario capable of inspiring 
and testing new population-genetic methods, a rare case in which multiple groups with a component of shared identity and descent lived over a large geographic range for a long period of time in a region of the world with a deep written record. From the viewpoint of scholarly fields that treat Jewish culture and history as the object of investigation, the use of genetics as an approach for understanding Jewish populations and their history taps into an intrinsic Jewish cultural interest in origins and migrations, a recognition of nonidentical but overlapping senses of Jewish group membership-from cultural to religious to genealogical-and the centrality to Jewish culture of the inheritance of Jewishness within families, as reflected in the title phrase, "From generation to generation."

Seeking to advance and understand trends in the genetics of Jewish populations, this special issue focuses on Jewish population genetics, setting new developments in relation not only to past population-genetic studies, but also in the broader context of Jewish Studies scholarship. The special issue builds upon a course of the same name that we held jointly in the Biology and Jewish Studies programs at Stanford University in the autumn of 2012, featuring the issue's contributors as guest lecturers. Human population genetics is, in part, a form of historical endeavor, potentially illuminating the effects of social practices such as endogamy and conversion, the history of population relationships, and the magnitude, direction, and timing of migration events. At the same time, the field can be viewed as historically situated, with its underlying assumptions, its expression in language, and its cultural reverberations and social implications subject to research in their own right. As a collection of articles spanning multiple forms of inquiry, the special issue aims to both present and contextualize current research, discussing its cultural environment and the challenges that lie ahead.

\section{The Papers}

Two research papers in the issue present modern studies in Jewish population genetics. Peter Oefner and colleagues investigate genetic variation in the Samaritans, a small Middle Eastern population that traces its heritage to a split from Israelite/Jewish populations during biblical times, and whose ancestry has been contentious for much of the time since. Oefner et al. (2014) consider Y-chromosomal and autosomal genetic variation in Samaritans alongside comparable variation in Jewish and non-Jewish populations sampled in Israel, as well as in relation to various populations from surrounding regions. Their analysis of genetic distances finds that the Samaritans have genetic similarity with Cohanim, members of the Jewish priestly caste. Curiously, each of the Samaritan male lineages - with the single exception of the Samaritans' own Cohen lineage-possesses a distinctive Y-chromosome lineage closely related to the "Cohen Modal Haplotype," the shared genetic lineage found at high frequency in both Ashkenazic and Sephardic Jewish males identifying as Cohen descendants. Oefner et al. report that the results strengthen the claims of the Samaritans themselves that they descend from the tribes of Israel at the time of the Assyrian exile in 722-720 BCE. 
Doron Behar, Mait Metspalu, and colleagues examine the origin of the Ashkenazi Jewish population, assembling a large genomic data set from across Europe, the Middle East, and the Caucasus region. Behar et al. (2014) frame their study in relation to a hypothesis that Ashkenazi Jews trace a large proportion of their ancestry to the Khazars, a Turkic-speaking group that lived in the Caucasus region 1,000 years ago, and they are the first to genomically test the Khazar hypothesis using an extensive sample of Caucasus populations. Employing several approaches to the analysis of population relationships, Behar et al. find no support for any special genetic similarity between Ashkenazi Jews and populations of the Caucasus, in fact identifying closer relationships between non-Jewish Caucasus populations and Jewish communities that historically resided in nearby places such as Azerbaijan, Georgia, and Kurdistan. They conclude that their study of a geographically more complete data set upholds earlier results that Ashkenazi Jewish genetic ancestry traces primarily to the Middle East and Europe, that Ashkenazi Jews share a substantial component of their genetic ancestry with other Jewish populations, and that no evidence supporting a historical genetic contribution from the Caucasus region is detectable. The findings of both this article and the article of Oefner et al. have implications for long-standing debates in the field of Jewish history on the origins of the Jews and their relationships to other populations.

Two commentaries seek to probe more directly the connections between present-day research on Jewish population genetics and other current and past areas of scholarship on Jewish populations. Historian John Efron examines the relationship between present-day Jewish population genetics and earlier nineteenth century research in physical anthropology (Efron 2014; for a sampling of the earlier scholarship, see Hart 2011). Efron's contribution aims to fill in the historical background of this past science, noting the rationale that motivated its researchers-some of whom were themselves Jewish-exploring the historical link between topics examined then and still considered now, and interpreting the meaning of their persistence. Efron's contribution includes a discussion of the history of the Khazar theory and its origins among Russian Jewish scientists of the late nineteenth century.

Geneticists today work hard to distinguish their assumptions and methods from the "race science" of the nineteenth and early twentieth centuries, a subject made infamous by its role as a rationale for Nazi eugenic policies and genocidal practice, and they do not identify at all with the race scientists' near-extinct intellectual tradition. Criticism of human population genetics, especially from scholarly fields that as a premise regard the scientific endeavor with skepticism, has asserted continuity between this earlier race science and present-day genetics researchan argument that in the view of many practicing geneticists dramatically exaggerates the linkages, belies their personal orientations toward their own research programs, underestimates the consideration they devote to challenges and subtleties of issues of race in genetics, and unfairly impugns the anti-racist positions that they may in fact hold with an intensity equal to that of the critics. Especially in the ways that it enters the public dialogue, 
however, present-day research in Jewish genetics has sometimes been treated as reintroducing a biological conception of Jewish identity that many may have thought permanently discredited by the Holocaust and its catastrophic racialization of Jewish identity.

At the same time that such research is raising concerns among those worried that it is reracializing Jewishness, it is also exerting a strong fascination both for Jews themselves and for others curious about possible Jewish ancestry in their own lineages. The story of one of our faculty colleagues at Stanford is typical of the pattern. She was surprised to find that a genetic test identified her as having 50\% Ashkenazi Jewish ancestry; the unexpected Jewish ancestry must have been contributed by two grandparents of uncertain descent, both adopted as young children in the same Midwestern town after riding orphan trains from New York around 1900, and drawn to each other through this shared experience. Recent research in Jewish genetics, such as the discovery of the Cohen Modal Haplotype (Skorecki et al. 1997; Thomas et al. 1998), has been broadly disseminated within Jewish communities. A wave of modern studies has used genetics to illuminate a variety of aspects of Jewish identity-to corroborate Middle Eastern origins in the background of different Jewish populations (Atzmon et al. 2010; Behar et al. 2010; Hammer et al. 2000; Kopelman et al. 2009), to assess the Jewish identity of non-Jewish groups such as the Lemba of southern Africa (Thomas et al. 2000), and even to help evaluate potential marriage partners within certain Jewish subgroups (Ekstein \& Katzenstein 2001). Populationgenetic research is clearly resonating in the broader Jewish public, not only as measured in the appearance of media reports and trade books on Jewish genetics (Entine 2007; Goldstein 2008; Ostrer 2012; Wheelwright 2012), but also in the sizeable Jewish representation in commercial genetic ancestry testing samples (Henn et al. 2012).

In her contribution to the special issue, anthropologist Susan Kahn juxtaposes two recent works that represent radically different perspectives on research in Jewish genetics, Harry Ostrer's Legacy: A Genetic History of the Jewish People (Ostrer 2012) and Nadia Abu El-Haj's The Genealogical Science: the Search for Jewish Origins and the Politics of Epistemology (El-Haj 2012). Ostrer's account is a book-length treatment of research in Jewish population genetics from the perspective of one of its central figures, advancing a view on the basis of genetics that Jewishness is biological; El Haj studies the cultural and rhetorical practices that have developed around recent genetics research, unconcerned with evaluating the scientific claims of the research itself, and treating the inquiry as social practice. In her account, the truth value of geneticists' conclusions is beside the point; geneticists are treated not as fellow scholars, but as anthropological subjects whose discourse and practices are studied for the cultural work they do within the broader society. Her book is written in the dispassionate style of conventional academic discourse and acknowledges no interests of its own, but it is critical of apparent interests at play in the styles of reasoning, potential biases, and social consequences of recent genetics research, and it aims to expose personal, communal, political, and commercial interests that penetrate the field. 
Kahn calls for a shared understanding between the positions represented by Ostrer and ElHaj, critiquing both Ostrer's provocative claims about the meaning of the scientific data and the aspersions cast by El-Haj on the science without attending to its actual content. Is Kahn's call for a shared understanding viable? El-Haj's critique runs deep, arguing that the entire enterprise of Jewish genetics is culturally and politically self-serving. It does not matter to her perspective whether the research is scientifically sound; what is relevant for her project is the subtle apparent continuities with earlier race science, the work the research does as a part of identity construction, and the rhetorical, cultural and political practice that it entails or enables. Does such a perspective have something to discern from people that it considers objects of study? El-Haj does not clarify whether population-genetic research-for Jews or for other population groups - can be a helpful form of inquiry under any circumstance. Would she think she has anything to learn at all from such research? And what can geneticists gain from a scholar like El-Haj who questions the very premises of their work, who seems uninterested in the truth claims that they make as genuine efforts to understand the world, and who reads their scientific efforts only with a hermeneutics of suspicion?

Whether bridging the difference is possible or not, Kahn's juxtaposition is instructive, as the two perspectives at least have the potential to learn from one another. Ostrer frames the evidence within a manifestly Jewish understanding of history. El-Haj's study, even if one is unpersuaded by its particular arguments, offers an opportunity to understand the implications of this work within another cultural perspective. What would happen if El-Haj's program were to engage her subjects with a willingness to give them more of their own voice, understanding how geneticists view their own work, how they frame its implications, and how they view their own disagreements and ambivalences? It need not require either side to abandon their different forms of inquiry to attend to what the other is saying. Whether or not a shared understanding is attainable, or would even be at all desirable to the protagonists of Kahn's essay, her contribution is a call for scholars of different perspectives to pursue mutual engagement at a deeper, more informed level.

The final paper in this issue, by archaeologist Aaron Brody and geneticist Roy King, represents one such example of mutual engagement. Brody \& King reach back to the earliest prehistory of the Jews, the origins of a distinct Israelite community within late Bronze Age or early Iron Age Canaan, asking whether genetics can help understand the formation of this identity. The ethnogenesis of the early Israelites, how they related to earlier Canaanites, and their eventual emergence as a distinct people that defined itself in opposition to neighboring Canaanites and Philistines, have been major preoccupations of Syro-Palestinian archaeology in recent decades. Can genetic evidence illumine this process of ethnogenesis? Brody \& King do not answer this question; rather, they review modern Jewish genetics in relation to the archaeological scholarship, and they attempt to envision future research linking the two forms of inquiry. Whether such research can actually be undertaken is an open question-it is unclear 
that the relevant ancient DNA materials can be retrieved from skeletal remains, not only for the usual practical reasons, but also because of cultural and legal barriers imposed in Israel on the use of human remains for research purposes.

The contribution of Brody \& King highlights a goal of this special issue of Human Biology in bringing together different forms of scholarship that bear upon the conduct and interpretation of research in the genetics of Jewish populations. Beyond the suggestions of Brody \& King for integrations of genetic and archaeological research, the special issue identifies a number of directions for future work, from new uses of identity-by-descent and spatial mapping, as reported by Behar et al., to proposals for incorporation of the history and consequences of the subject, as suggested by Efron and Kahn. Given the deep correspondences of the questions and preoccupations of Jewish genetics with the history of cultural scholarship on Jewish populations, we expect that forms of integrated analysis will be valuable for future advances.

Acknowledgments. We are grateful for financial support from several academic units at Stanford, including the Center for Comparative Studies in Race and Ethnicity, the EcoEvo group in the Department of Biology, the Morrison Institute for Population and Resource Studies, the Stanford Center for Population Research, and the Taube Center for Jewish Studies (with funding provided by the Koret Foundation). We also thank the editors of Human Biology-Franz Manni for enthusiastic support and advice at an early stage, and Brian Kemp and Ripan Malhi for assistance with editorial management of some of the papers.

\section{Literature Cited}

Atzmon, G., Hao, L., Pe'er, I., Velez, C., Pearlman, A., Palamara, P.F., Morrow, B., Friedman, E., Oddoux, C., Burns, E., and H. Ostrer. Abraham's children in the genome era: major Jewish diaspora populations comprise distinct genetic clusters with shared Middle Eastern ancestry. Am. J. Hum. Genet. 86:850-859.

Behar, D.M., Metspalu, M., Baran, Y., Kopelman, N.M., Yunusbayev, B., Gladstein, A., Tzur, S., Sahakyan, H., Bahmanimehr, A., Yepiskoposyan, L., Tambets, K., Khusnutdinova, E.K., Kushniarevich, A., Balanovsky, O., Balanovsky, E., Kovacevic, L., Marjanovic, D., Mihailov, E., Kouvatsi, A., Triantaphyllidis, C., King, R.J., Semino, O., Torroni, A., Hammer, M.F., Metspalu, E., Skorecki, K., Rosset, S., Halperin, E., Villems, R., and N.A. Rosenberg. 2014. No evidence from genome-wide data of a Khazar origin for the Ashkenazi Jews. Hum. Biol. (in press).

Behar, D.M., Yunusbayev, B., Metspalu, M., Metspalu, E., Rosset, S., Parik, J., Rootsi, S., Chaubey, G., Kutuev, I., Yudkovsky, G., Khusnutdinova, E.K., Balanovsky, O., Semino, O., Pereira, L., Comas, D., Gurwitz, D., Bonne-Tamir, B., Parfitt, T., Hammer, M.F., Skorecki, K., and R. Villems. 2010. The genome-wide structure of the Jewish people. Nature 466:238-242.

Brody, A.J., and R.J. King. 2014. Genetics and the archaeology of ancient Israel. Hum. Biol. (in press). Carmelli, D., and L.L. Cavalli-Sforza. 1979. The genetic origin of the Jews: a multivariate approach. Hum. Biol. 51:41-61. 
Efron, J.M. 2014. Jewish genetic origins in the context of past historical and anthropological inquiries. Hum. Biol. (in press)

Ekstein, J., and H. Katzenstein. 2001. The Dor Yeshorim story: community-based carrier screening for Tay-Sachs disease. Adv. Genet. 44:297-310.

El-Haj, N.A. 2012. The genealogical science: the search for Jewish origins and the politics of epistemology. Chicago: University of Chicago Press.

Entine, J. 2007. Abraham's children: race, identity, and the DNA of the chosen people. New York: Grand Central Publishing.

Goldstein, D.B. 2008. Jacob's legacy: a genetic view of Jewish history. New Haven, CT: Yale University Press.

Hammer, M.F., Redd, A.J., Wood, E.T., Bonner, M.R., Jarjanazi, H., Karafet, T., Santachiara-Benerecetti, S., Oppenheim, A., Jobling, M.A., Jenkins, T., Ostrer, H., and B. Bonne-Tamir. 2000. Jewish and Middle Eastern non-Jewish populations share a common pool of Y-chromosome haplotypes. Proc. Natl. Acad. Sci. USA 97:6769-6774.

Hart, M. (ed.) 2011. Jews and race: writings on identity and difference 1880-1940. Waltham, MA: Brandeis University Press.

Henn, B.M., Hon, L., Macpherson, J.M., Eriksson, N., Saxonov, S., Pe'er, I., and J.L.Mountain. 2012. Cryptic distant relatives are common in both isolated and cosmopolitan genetic samples. PLoS One 7:e34267.

Kahn, S. M. 2014. Who are the Jews? New formulations of an age-old question. Hum. Biol. (in press).

Karlin S., Kenett R., and B. Bonné-Tamir. 1979. Analysis of biochemical genetic data on Jewish populations: II. Results and interpretations of heterogeneity indices and distance measures with respect to standards. Am. J. Hum. Genet. 31:341-365.

Kopelman, N.M., Stone, L., Wang, C., Gefel, D., Feldman, M.W., Hillel, J., and N.A. Rosenberg. 2009. Genomic microsatellites identify shared Jewish ancestry intermediate between Middle Eastern and European populations. BMC Genet. 10:80.

Oefner, P., Hölzl, G., Shen, P., Shpirer, I., Gefel, D., Lavi, T., Woolf, E., Cohen, J., Cinnioglu, C., Underhill, P.A., Rosenberg, N.A., Hochrein, J., Granka, J.M., Hillel, J., and M.W. Feldman. 2014. Genetics and the history of the Samaritans: Y-chromosomal microsatellites and genetic affinity between Samaritans and Cohanim. Hum. Biol. (in press).

Ostrer, H.B. 2012. Legacy: a genetic history of the Jewish people. New York: Oxford University Press.

Skorecki, K., Selig, S., Blazer, S., Bradman, R., Bradman, N., Waburton, P.J., Ismajlowicz, M., Hammer, M.F. 1997. Y chromosomes of Jewish priests. Nature 385:32.

Thomas, M.G., Parfitt, T., Weiss, D.A., Skorecki, K., Wilson, J.F., le Roux, M., Bradman, N., and D.B. Goldstein. Y chromosomes traveling south: the Cohen Model Haplotype and the origins of the Lemba-the "Black Jews of Southern Africa." Am. J. Hum. Genet. 66:674-686.

Thomas, M.G., Skorecki, K., Ben-Ami, H., Parfitt, T., Bradman, N., and D.B. Goldstein. 1998. Origins of Old Testament priests. Nature 394:138-140.

Wheelwright, J. 2012. The wandering gene and the Indian princess: race, religion, and DNA. New York: Norton. 